\title{
Uncharted territories of transnational design history with particular reference to Turkey
}

\author{
Tevfik Balcioglu / Yaşar University / Izmir / Turkey
}

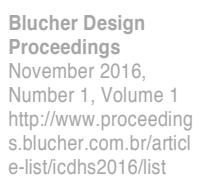

\begin{abstract}
This paper unfolds an interesting characteristic of transnational design based on observations in Turkey. This may be titled as "A Non-Reflective Transnational Dissemination of Impacts," which denotes one directional process where design ideas run from centre to periphery but not vice versa in particular areas. For instance, Baroque and Rococo architecture were introduced to the Ottomans in the 19th Century and the Balian Family designed many ostentatious buildings in Istanbul; what impact have they made on Italian or French Architecture? None? Bruno Taut who is famous with his Glass House designed in 1914 Deutsche Werkbund Exhibition, moved to Turkey in 1936, built several important buildings including a "pagoda house", died in 1938 and buried in Istanbul. How many of his architectural work in Turkey were acknowledged in Global Western design history? None? These cases constitute a ground to explore and develop the concept of "A Non-Reflective Transnational Dissemination of Impacts".
\end{abstract}

\section{Keywords}

Transnational history, design, Bruno Taut, Balian family, Turkey

\section{Introduction}

This paper aims at revealing and discussing the particular characteristics of transnational design history that we have encountered in Turkey. In order to study the subject with a coherent approach, the understanding of transnational history and its interpretation for the field of design will be briefly revealed. This will help define a conceptual territory within which an undefined area will be looked into with an example from Design History in Turkey.

\section{Transnational history}

The expression of transnational is not new. It goes back to 1862 when German philologist Georg Curtius discussed 'transnational' languages in Leipzig (Macdonald, 2013). It took six years for its first English appearance, in an article published in Princeton Review (Macdonald, 2013). Nevertheless, the term gained widespread use and enriched substance since 1990, which has opened avenues for serious discourse as well as offering new ways for history researches (Kikuchi, 2014; Friberg, 2007; Macdonald, 2013). The rise of globalisation debates and the issues of migration are amongst the leading factors bringing the term transnationalism on the agenda. Simon Macdonald gives a good account of the evolvement of the term and concludes: "Akira Iriye's influential call in 1989 for new research 'to search for historical themes and conceptions that are meaningful across national boundaries' accelerated the emergence of transnational histories" (2013, p. 4).

The relationship, meaning and position of transnational histories with respect to comparative studies, global and world histories were much discussed (Bayly, 2006). It would not be right to draw a straightforward conclusion and give precise definitions of each one but a few sentences formulating the framework of this paper would be useful for the arguments presented later.

Comparative studies have their own aims and objectives and are restricted to nations and states. The critical writers underline that comparative studies could be strengthening the national version of history, may treat "its cases as autonomous and ignores the link between them". In defence of comparative studies, Frieberg, Hilson and Vall argue that "comparative methods, practiced as a heuristic search for similarities and differences 
across space, may transcend national borders without reinforcing dominant national paradigms" (2007, p.735). Referring to Miller's article, many commentators would agree that comparative and transnational histories are not mutually exclusive, but they are complementary although the scope of transnational studies is much wider and inclusive. (Szélpál, 2009).

The differences between world and global histories are vague as differences between transnational histories and comparative histories. Bayly has stated "that the distinctions between world, global, and transnational history have never adequately been explained" (2006, p. 1442). His explanation is to highlight the minor distinctions: "I get the sense that 2trans- national history' stands in the same relationship to 'international history' as 'global history' does to 'world history': that it is much the same thing, except that the term 'transnational' gives a sense of movement and interpenetration" (Bayly, 2006). lan Tryyell's observations are in the same direction: "The new transnational history was related to, but not the same as globalization, world history, and comparative history" (2007, p. 1).

Kikuchi gave a good account of these debates and analysis of the concepts with special emphasis on their reflection in design history (2014). To focus on the subject of this paper, her description of transnational history will be utilised for it is pragmatic and instrumental: "The transnational approach identifies the porousness of national borders and allows us to see different flows of human activities, including interactions of people, objects, ideas and art and design movements; otherwise the perspectives are delimited by national borders" (2014, p. 325). Actually, this is a definition accepted by many scholars, as Thelen writes "We wanted to explore how people and ideas and institutions and cultures moved above, below, through and around as well as within the nation-state" (1999, p. 967).

\section{Two cases from Turkey: Bruno Taut and Balians}

Taking these sentences as starting points, two hypotheses will be formulated based on specific cases concerning design history in Turkey. The purpose of these suppositions is to raise questions, touch upon uncharted territories and perhaps generate new perspectives for the further development of transnational design history.

The first situation is Non-Reflective Transnational Dissemination of Impacts, which denotes one directional process where design ideas mostly run from centre to periphery but not vice versa in particular areas. An excellent example is Bruno Taut who was born in Konigsberg in 1880, studied architecture in Stuttgart, designed the legendary Glass Pavilion for 1914 Deutsche Werkbund Exhibition, built many housing compounds in Berlin, moved to Japan in 1933 and finally relocated in Turkey in 1936, where he died and was buried in Istanbul, just after he designed the catafalque for Mustafa Kemal Ataturk.

Taut was appointed as the first Head of Architecture Department at the Fine Art Academy in Istanbul. Although his life in Turkey was short and limited to his last two years, the amount of work he created and his influence in the constitution of modern Turkish architecture is considerable (Aslanoglu, 1976). Taut had worked as a practicing architect for the Turkish State as much as he operated as a head of department. Among the many buildings he designed, the Faculty of Languages, History and Geography of Ankara University is particularly important for its scale, appearance, materials selected and details which has made it a manifest for Modern architecture in late

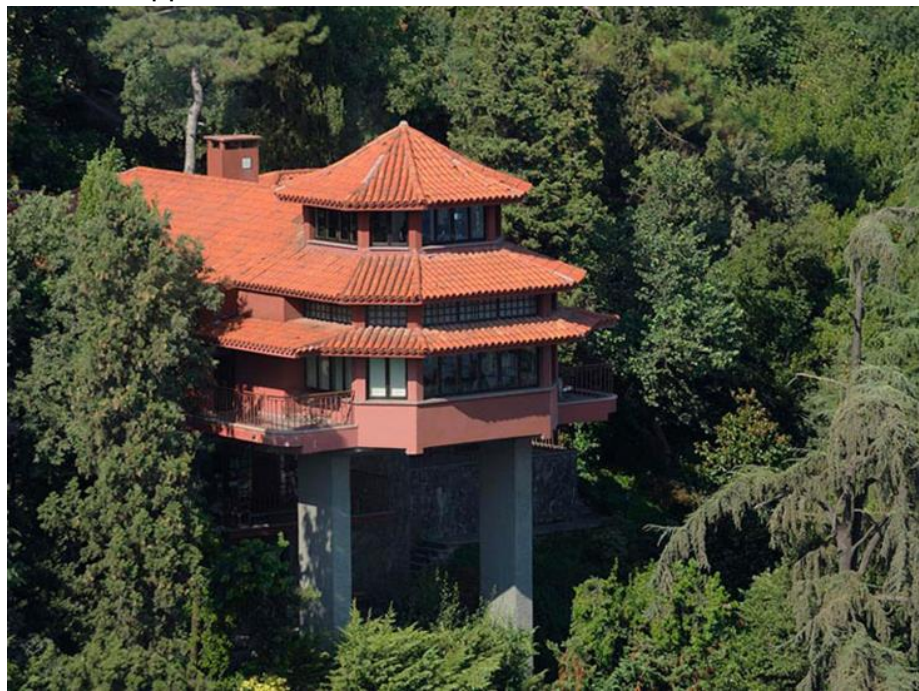

Figure 1: Pagoda House by Bruno Taut, Istanbul. (Photo: Courtesy of Piramit Haber). 1930's of Turkey. Amongst his other works, he made another fascinating move: As a cultural agent and a restless soul, after his experience in Japan, Bruno Taut designed and built a 'Pagoda House' for himself in Istanbul (see figure 1).

When Taut's life, experiences and successes in various countries are taken into account, his irrefutable role and undeniable value for international architecture becomes apparent. In this respect, we can assume and expect that his work is the subject of intensive research, leading to vast quantities of publications. Unfortunately, this is not the case. As an exception to this general trend, we may include the works of Manfred Speidel - a Bruno Taut 
expert, an early text by Aslanoglu (Aslanoglu, 1976), a book section by Bozdogan (1997), an article by Erdim (2007) and the seminal book of Esra Akcan published in 2012. Most of the researchers on Bruno Taut have often focused on his worldwide known 'Glass House' or his achievements in national scopes, for instance his housing schemes in Berlin, his buildings and pedagogical role in Turkey or his endeavours in Japan.

Three issues surface here: $A$ ) he is underrated and ignored by many historians in the West. B) his works in countries far from the West, namely in Turkey and Japan, remain distant from current design discourses and have been missed out c) National histories and comparative studies have failed to uncover his transnational significance.

Reyner Banham's remark on Taut supports these observations. Referring to his 1914 Glass House, Banham writes: "Quite apart from the possibility of its having been influenced by Paul Scheerbart's book, Glasarchitektur which came out in the same year, its rare qualities suggest that it was produced in a moment of genius that Taut was unable to repeat" (1989, p. 81). Is “...unable to repeat" not a judgemental statement proposed without evaluating Taut's later work in Japan and Turkey?

Inci Aslanoglu encounters another kind of reserved approach to Taut (Aslanoglu, 1976, p. 35). Aslanoglu, referring to Walter Segal's article (1972) notes that post war architectural historians had focused sufficiently on Bauhaus and many German émigré architects but they avoided Taut and his work for this is a very difficult subject matter that they did not know how to handle or classify. Thanks to a transnational approach, Esra Akcan's has worked to overcome these difficulties 40 years after those sentences were written (2012). Akcan prefers the word 'translation' instead of 'transnational' in her book. However, her definition of the former is not dissimilar to the definitions of the 'transnational' that we use in here. "... (A) term I particularly find accessible since it is a common experience, whether one has translated between two languages, mediums or places. .. a cultural flow from one place to another." (2012. p. 4)

Nevertheless, even Akcan's work serves to prevent further enquiries: Taut's house in Istanbul known as Japanese House, due to its pagoda like appearance, offers a wonderful view of the Bosporus due to its architectural configurations. But, why 'pagoda', a form used for temples in Japan, should be employed in Istanbul for a dwelling is not very clear. Akcan considers it as "critical and innovative gesture" while Taut, in a letter to Walter Segal, stresses that his designs are samples of his architectural understanding (2012). Bozdogan underlines that this house "stands out from the rest of his built work in Turkey as the symbol of his preoccupation with the lessons of vernacular in Japan and Turkey" (1997, p. 185-6). If we take the Turkish design concepts used in this building into account, one may conclude that Taut has created an amalgamation of transcultural design appropriate to geography and climate with innovative features reflecting a contemporary taste of his own.

What effect has this house and Taut's other works in Turkey has made in architectural practice and education in Japan or in the West has not surfaced in this initial survey. Probably none. Is it because Istanbul and Taut were not part of cutting edge design discourse in the West? Could we assume that this may be a NonReflective Transnational Dissemination of Impacts, a one directional process where design ideas amongst others, flow from centre to periphery but not vice versa? Could the centre (or some countries of the centre) are more introvert and self-oriented and thus, closed to the periphery at certain time periods?

This brings the second example to the fore for examination: The Balian Family (Balyan in Turkish). Three generations of Balian Family, members such as Kirkor (1764-1831), his son Karabet (1800-1866), and his sons Nikogos (1826-1858), Sarkis (1835-1899) and Agop Balyan (1830-1875) were the key figures of $19^{\text {th }}$ Century Ottoman architecture (Goodwin, 1992). They were working for Ottoman Sultans and had erected the most important buildings, comprising of Dolmabahce, Ciragan and Beylerbeyi Palaces, Ortakoy and Valide Sultan Mosques, Beyazit and Dolmabahce Clock Towers, and houses at Akaretler in Istanbul to name but a few. Nikogos, Sarkis and Agop had studied at Sainte-Barbe College at Paris where Alexandre Labrouste, brother of renowned French Architect Henri Labrouste was the head. Goodwin has written years ago about their attendance to Sainte-Barbe College and underlines how Henri Labrouste was influential on Nikogos (Goodwin, 1992, p. 419).

What concerns us within the scope of this paper is how Balian's works are treated by national and transnational histories. The situation from the viewpoint of former is not something that one can be proud of. Deliberating the great numbers of building they have built more than a century ago, we discern that studies on their works are limited, publications are inadequate and is mostly comprised of articles, except for a few books on the subject. The main reason for the shortage of knowledge may derive from the "little information concerning Balians themselves in the documentation of the Ottoman archives" (Wharton, 2010, p. 93). The list published in the book "Armenian Architects of Istanbul" portraits well the scenery and inevitably leads to the following critical observations: 
First. Although in recent years the variety of commentators has increased, and has been mostly and understandably researchers of Armenian origin, who study architecture of the Balian family. Benefiting form Armenian sources is obviously an advantage to get further information at least for cross checking.

Second. Up until a few decades ago, some historians kept a distance from Balian's designs and mentioned them in nothing more than a few superfluous sentences. When mentioned, Balian's architecture is neither praised nor acknowledged properly. A respected architectural historian, Abdullah Kuran, successfully describes several 19th Century Balian buildings without mentioning originators' names in the text but in the footnotes only (Kuran, 2012). For an art Historian, Aslanapa, Ciragan Palace is a hybrid example of a stupefaction period in which foreign constructions were destroying the portrait of the city where Italian architects were prevailing (Diez \& Aslanapa, 1955). Arseven writes that Ottoman architecture was in total collapse in 1861 and adds, "respected Rum and Italian architects of that time, used to make sort of weird buildings totally alien to Turkish Art" (Arseven, 1984, p. 180). (Rums are people who lived in East Roman Empire. As a Turkish expression, in common parlance, it refers to people of Greek origin who live in Ottoman territory as her citizen).

Third. The role of Armenian architects in Turkey is a minefield and an ideological battleground.

For example, Aygul Agir's assertion is that there is lack of evidence to support that Balian brothers officially studied in France (Agir, 2005). Alyson Wharton thinks the opposite and tries to prove it (Wharton, 2016). In a conference paper Serafettin Deniz claims that Nikogos Balian could not have built Ortakoy Mosque (Deniz, 2006). Selman Can takes the proclaims further: for him Balians are not architects but constructors. Having said that he then gives a list of architects as the designers of many buildings ascribed to Balians (Elmas, 2016.) While nationalist history discourse attempts to ignore or discredit Balians or try to diminish their role in the design and construction of notable premises certified to them, their church designs are not even mentioned or not considered as part of Ottoman Architecture (Kuban, 2007).

Irvin Cemil Schick has very recently taken part in the writing of an edited book entitled "Turk Mimarisinde Iz Bırakanlar" (Those Leaving Traces in Turkish Architecture). The Ministry of Environment and Urban Planning has initiated an edited book project on Turkish architecture. Schick has been invited to be become a member of editorial board. He realises that there is almost no foreign or non-Muslim architect in the list prepared. He insists that the list needs alterations and succeeds in getting some names included. His experience with the authorities and his narration of the publication process of the book illustrates clearly and ironically the current state of a prevailing nationalist attitude (Schick, 2016).

National histories do not grasp entirely the realities of fundamentally homogenous but at the same time multi-ethnic structure of Ottoman urban culture (Cerasi, 1988). Edhem Eldem articulates the situation eloquently: "Nation-sates are often incapable of understanding empires" (2010, p. 13).

To this end, it becomes evident that transnational history finds another fecund soil within which to grow justification of its presence and effectiveness. Exactly here, the aforementioned question surfaces again: What impact has Balians' Baroque and Empire style architecture made on the global or world history? Afife Batur and many other scholars accentuate that their work is not a copy of Western architecture but an original approach adopting and taking it further, which definitely, requires a substantial investigation.

What can be said regarding Taut could also be reiterated in this point: Non-Reflective Transnational Dissemination of Impacts could also be valid for Balians. In other words, one would always like to know the influence and contribution of their architecture beyond the borders of Ottoman Empire if there is any. Where does this stand in relation to conventional Baroque and Empire style and within the dominant discourse? How could transnational history draw a perspective within these niches of uncharted territories?

\section{Conclusion}

These questions are intended to indicate the necessity of new approaches as well as new directions needed in the design history of Turkey. However, the current nationalist streams also present gap, voids and domains to be scrutinized. A nation state born out of the ashes of a huge and cosmopolitan empire is substantially different than a nation state based on one or two ethnics groups. In a sense, Turkey is to suffer from non-comprehension and nonembodiment of these diversities, which render the materialization of various fractions, societies, and communities, religious and political factions possible. This fragmentation causes and forces each group to search for and built its own identity. Historiography as well as design appears to be the victim of these affords, for they are being used and abused from time to time (Balcioglu, 2012; Balcioglu \& Emgin, 2014). Therefore, 'Trans-community Design Trends' drives from this multi-layered, and perhaps, in a positive remark, colourful mosaic but at the same time 
chaotic situation

As a corollary, this paper draws the attention of design historians focusing on Turkey on two methodological concerns: Non-Reflective Transnational Dissemination of Impacts and Trans-community Design Trends. These two unexplored area of transnational historiography, which definitely demands further study, may not be Turkish specific peculiarity, and might be applicable in and for other countries as well. Therefore, historians have to be prepared to construct bridges over troubled waters.

\section{References}

Agir, A (2005) Balyanlar'in Egitimi Uzerine Notlar. In Agir, A., Mazlum, D., \& Cephanecigil, G. Afife Batur'a Armagan. Mimarlik ve Sanat Tarihi Yazilari (pp. 65-71). Istanbul: Literatur.

Akcan, E. (2012) Architecture in Translation: Germany, Turkey and The Modern House. Durham \& London: Duke University Press.

Akcan, E. (2000) Orientalism and Melancholy: Bruno Taut in the East. In L. V. Wells-Bowie (Ed.), 88'th ACSA Annual Meeting Proceedings, (pp. 263-272). Heterotopolis.

Arseven, C. E. (1984) Turk Sanatı (Turkish Art). Istanbul: Cem Yayinevi.

Aslanoglu, I. (1976) Disavurumcu ve Usçu Devirlerinde Bruno Taut (1880-1938). METU Journal of Architecture, 2 (1), 35-48.

Balcioglu, T. (2012) Redesigning Turkish Cult Objects: From Tradition to 'Modern'. In P. L. Farias and et al (Eds), Design Frontiers: Territories, Concepts, Technologies (pp. 130-134). San Paolo, Brazil: Blucher.

Balcioglu, T. \& Emgin, B. (2014) Recent Turkish Design Innovations: A Quest for Identity. Design Issues, 30 (2), 97-111.

Banham, R. (1989) Theory and Design in the First Machine Age. Cambridge, Massachusetts: The MIT Press.

Bayly, C. A., Beckert, S. \& Connely, M. I. (2006) AHR Conversation: On Transnational History. The American Historical Review, 111 (5).

Bozdogan, S. (1997) Against Style: Bruno Taut's Pedagocial Program in Turkey. In M.Pollak, The Education of the Architect: Historiography, Urbanism and the Growth of Architectural Knowledge (pp. 163-192). Cambridge: The MIT Press.

Cerasi, M. (1988) Late Ottoman Architects and Master Builders. Muquarnas, 5, 87-102.

Deniz, S. (2006) Ortakoy Camii'nin Insa Surecinde Gayri Muslim Yonetici, Usta ve Tuccarların Rolu. In K. Kahraman (Ed.), 150. Yilinda Dolmabahce Sarayi (pp. 693-706). Ankara: TBMM Milli Saraylar Daire Baskanligi.

Diez, E. \& Aslanapa, O. (1955) Turk Sanatı. Istanbul Universitesi Edebiyat Fakultesi Yayinlari.

Eldem, E. (2010) Discovering "Other" Architects. In H. Kuruyazıcı (Ed.), Armenian Architects of Istanbul (pp. 12-17). Istanbul: International Hrant Dink Foundation Publications.

Elmas, D. (2016) Antoloji.com. Retrieved 3. 14, 2016, from Tarihi bir gercek aydinliga cikiyor...'Balyanlar' mimar degildi. : http://www.antoloji.com/tarihi-bir-gercek-aydinliga-cikiyor-balyanlar-mimar-degildi-mutlakaoku-siiri/

Erdim, B. (2007) From Germany, to Japan and Turkey: Modernity, Locality and Bruno Taut's Transnational Details from 1933-38. Lunch 2, Journal of the University of Virginia School of Architecture, 103-115.

Friberg, K., Hilson, M. \& Vall, N. (2007) Reflections on trans-national comparative history from an AngloSwedish perspective. Historisk Tidskrift, 127 (4), 717-737.

Goodwin, G. (1992) A History of Ottoman Architecture. London: Thames and Hudson.

Kikuchi. Y. (2014) Transnational Modern Design Histories in East Asia: An Introduction. Journal of Design History, 27 (4), 323-334.

Kuban, D. (2007) Osmanli Mimarisi (Ottoman Architecture). Istanbul: YEM Yayinlari.

Kuran, A. (2012) Architecture in Turkey, from the Seljuks to the Republic. Istanbul: Türkiye Is Bankasi.

Macdonald, S. (2013) Transnational history: a review of past and present scholarship . Retrieved February 20, 2016, from https://www.ucl.ac.uk/cth/objectives/simon macdonald tns review

Segal, W. (1972) About Taut 1880-1938. Architectural Review, v. 151, n. 899, p.25.

Szélpál. L. (2009) Transnational History: An American Perspective. Americana: E-Journal of American Studies in Hungary, 5 (2).

Thelen, D. (1999) The Nation and Beyond: Transnational Perspectives on United States History. The Journal of American History, 86 (3).

Tyrrell. I. (2009) Reflections on the transnational turn in United States history: theory and practice. Journal of Global History (4), 453-474.

Tyrrell, I. (2007, January) IAN TYRRELL. Retrieved February 20, 2016, from https://iantyrrell.wordpress.com/: https://iantyrrell.wordpress.com/what-is-transnational-history/

Wharton, A. (2015) Armenian Architects and 'Other' Revivalism. In A. Lepine; M. R Lodder \& R. McKever. (Eds). Revival: Memories, Identities, Utopias. London: Courtauld Books Online. (pp. 150-167). 
Wharton, A. (2010) Mosque Building in the Tanzimat Period. In H. Kuruyazıcı, \& H. Kuruyazıcı (Ed.), Armenian Architects of Istanbul (pp. 91-105). International Hrant Dink Foundation Publications.

Wharton, A. (2016) The Balyan Family and the Linguistic Culture of a Parisian Education. International Journal of Islamic Architecture, 5 (1), 39-71.

\section{Biographical note}

Professor of Design, (Vice Rector, 2012-15) Yasar University, Izmir, Turkey. Graduated from METU, attended RCA, taught at Goldsmiths' College \& KIAD, UK; Founding Dean of Faculty of Fine Arts \& Design at IUE, Founding President of Design \& Design History Society, (4T); editor of several books and journal issues. 